\title{
Insights into academic feasibility at the KIT: a mixed-methods exploration of the department of mechanical engineering
}

\author{
Ines Langemeyer, Nadja Schlindwein
}

Department of Humanities and social sciences, institute for vocational education and general education, Karlsruhe Institute of Technology (KIT), Germany.

\begin{abstract}
As part of their accreditation procedure, universities have to ensure academic feasibility of their study courses. Against that backdrop, student's workload and study conditions are focused as indicators of quality. However, this prioritization offormal criteria is defined by the module handbooks rather than by the students themselves. Therefore, a mixed-methods-analysis at the Karlsruhe Institute of Technology (KIT) was conducted to shed light on these issues: How can individual expectations and requirements of students towards the academic learning settings be incorporated into quality assessment? Which opportunities of individual development for students exist in the academic setting and do they differ with regard to different departments at the KIT? The data of surveys completed by 324 students of the department of mechanical engineering and 242 students of the department of economics and management at the KIT are the basis of our analysis. The empirical analysis via chi-squaretest and Mann-Whitney-U-Test indicates significant distinctions between students of both departments at the KIT concerning their experiences with research and inquiry and their motives for enrolling to university courses. Further analyses via interviews are planned to reveal the complex chains of reasons for this research results such as considerations of course characteristics and cultural condition.
\end{abstract}

Keywords: Higher education; academic feasibility; mechanical engineering. 


\section{Introduction}

When universities are to ensure academic feasibility of their study programs as part of their accreditation procedure, as a rule only a balanced students' workload and the assessment of study conditions are focused as indicators of quality (Langemeyer \& Schlindwein, 2021). Emphasizing the "practical relevance" of a degree course as well as occupational qualifications is widely argued as important for so-called knowledge society (Tremp, 2018). However, this prioritization of formal criteria is defined by the module handbooks rather than by the students themselves. If higher education teachers invest enough time to develop the curriculum according to learning achievements and aims is an open question. Following similar questions of interest within the field of higher education, Trigwell and Prosser (2004) revealed the importance of student's perceptions of their learning settings and environments. Therefore, a mixed-methods-analysis at the Karlsruhe Institute of Technology (KIT) was conducted to shed light on these issues: How can individual expectations and requirements of students towards the academic learning settings be incorporated into quality assessment? Which opportunities of individual development for students exist in the academic setting and do they differ with regard to different departments at the KIT? What can be detected from assessing research-driven teaching and learning from students' perspective?

\section{Design and methods}

Surveys completed by 1482 students of all departments at the KIT in 2016 are the basis of our analyses. The questionnaire includes items about students' experience with various didactic elements of research and inquiry in their learning setting in higher education. Furthermore, students' motives for enrolling to university courses and their expectations about their individual development were assessed. In previous empirical work, different methodological approaches have shown significant distinctions concerning the experiences with and judgements about various didactic elements of research and inquiry, learning strategies and study requirements of students (Langemeyer \& Schlindwein, 2021).

In the present study, the subsample of 324 students of the department of mechanical engineering and the subsample of 242 students of the department of economics and management at the KIT were used for a comparison. The following questions were scrutinized via mixed-methods-approach at the Karlsruhe Institute of Technology (KIT): How can individual expectations and requirements of students towards the academic learning settings be met? Which opportunities of individual development do students have in their particular academic setting and how do they differ with regard to the chosen departments at the KIT? The analysis then focused on the use of particular experience with didactic elements such as informing students about currently published research results or challenges to plan and conduct independently a research project. Students' motives for enrolling to university 
courses were also assessed, such as high-income opportunities, preferring a career in science or engaging with scientific problems and issues.

\subsection{Experience with didactic elements of research and inquiry}

Via chi-square-test, significant distinctions between students of the department of mechanical engineering and students of the department of economics and management at the KIT concerning their experiences with various didactic elements of research and inquiry were confirmed. Table 1 shows the selected experiences with didactic elements the survey contained and the results of the analysis.

Table 1. Results of chi-square test concerning experiences of research and inquiry between students of the department of mechanical engineering and students of the department of economics and management at the KIT.

\begin{tabular}{lccccc}
\hline Variable & $\chi \mathbf{2}$ & $\mathbf{F G}$ & $\mathbf{p}$ & $\boldsymbol{\omega 2}$ \\
\hline researching independently a certain theme (- research content) & 3.38 & 1 & .06 & -.07 \\
familiarising with current research results & 6.89 & 1 & .00 & -.11 \\
using examples of research for illustration & .58 & 1 & .44 & .03 \\
participating in the work of research projects at the institute/chair & 6.83 & 1 & .00 & .11 \\
developing research questions & 4.10 & 1 & .04 & -.08 \\
running experiments/small projects & 6.81 & 1 & .00 & .11 \\
developing and planning a research project & .078 & 1 & .78 & .01 \\
conducting independently a research project & .95 & 1 & .32 & .04 \\
exploring interrelations in a particular field & 1.23 & 1 & .26 & -.04 \\
participating in excursions & 9.17 & 1 & .00 & .12 \\
acquiring basic knowledge & .72 & 1 & .39 & .03 \\
\hline
\end{tabular}

Source: own elaboration based on data from 2016.

The analysis shows that significant distinctions can be found with regard to the experiences of familiarising students with current research results, participating in the work of research projects at the institute/chair, developing research questions, running experiments/small projects and participating in excursions. The result that students of mechanical engineering learn significantly less about current research results than their peers in the department of economics and management at the KIT indicates that basic knowledge as it is taught and acquired during the first year(s) of their study program is considered as approved more than the equivalent knowledge in economics. However, the subsample of students of the 
department of mechanical engineering has a higher level with regard to participating in research projects at the institute/chair, running experiments/small projects and participating in excursions than students of the department of economics and management. In the next section, it is analyzed how these differences correspond with significantly different expectations towards academic education by the respective groups of students.

\subsection{Motives for enrolling to university courses}

To analyze differences between both groups of students of the two departments at the KIT items concerning their motives for enrolling to university courses are considered. The MannWhitney-U-Test as non-parametric procedure was conducted (see table 2). The results show that students of the department of mechanical engineering have significantly higher mean ranks with regard to the interest in scientific work, striving for an academic career and engagements to improve society. They also show a significantly higher interest in their disciplinary subject as a motive for enrolling to university courses. However, students of the department of economics and management point out earning opportunities as motive for entering higher education and have significantly higher values here than the students of mechanical engineering. Furthermore, the results also indicate that students of the department of economics and management are influenced more strongly by expectations of their parents, family, peers etc. than students of the department of mechanical engineering. This indicates that there are more students in economics who want to please family or peers by enrolling into higher education than in the subsample of mechanical engineering. However, this information must not be overestimated since the overall number of students' who agreed with this item is small. 
Table 2. Results of Mann-Whitney-U-Test analysing motives for enrolling to university courses of students of the department of mechanical engineering and students of the department of economics and management at the KIT.

\begin{tabular}{|c|c|c|c|c|c|c|c|}
\hline \multirow[b]{2}{*}{ Variable } & \multicolumn{2}{|c|}{$\begin{array}{l}\text { Students of the } \\
\text { department of } \\
\text { mechanical } \\
\text { engineering }\end{array}$} & \multicolumn{2}{|c|}{$\begin{array}{l}\text { Students of the } \\
\text { department of } \\
\text { economics and } \\
\text { management }\end{array}$} & \multirow[b]{2}{*}{$\mathbf{U}$} & \multirow[b]{2}{*}{$\mathbf{z}$} & \multirow[b]{2}{*}{$\mathbf{p}$} \\
\hline & $\mathbf{N}$ & $\begin{array}{c}\text { Mean } \\
\text { rank }\end{array}$ & $\mathbf{N}$ & $\begin{array}{c}\text { Mean } \\
\text { rank }\end{array}$ & & & \\
\hline $\begin{array}{l}\text { Preferring higher education } \\
\text { than vocational training }\end{array}$ & 320 & 286.58 & 239 & 271.19 & 33135.5 & -1.1 & .24 \\
\hline $\begin{array}{l}\text { Higher education as future- } \\
\text { oriented investment }\end{array}$ & 319 & 278.38 & 239 & 280.99 & 37764.5 & -.21 & .83 \\
\hline Earning opportunities & 319 & 267.03 & 239 & 296.14 & 34142.5 & -2.1 & .02 \\
\hline Improvement of society & 317 & 291.24 & 238 & 260.37 & 33526.0 & -2.2 & .02 \\
\hline Engaging with social issues & 316 & 268.69 & 238 & 289.20 & 34820.0 & -1.5 & .13 \\
\hline Social commitment & 317 & 266.91 & 237 & 291.66 & 34208.5 & -1.8 & .07 \\
\hline Scientific working & 318 & 311.57 & 237 & 232.96 & 27009.0 & -5.7 & .00 \\
\hline Aspiring a career in science & 316 & 303.52 & 238 & 242.95 & 29381.0 & -4.4 & .00 \\
\hline $\begin{array}{l}\text { Engaging with scientific } \\
\text { issues }\end{array}$ & 319 & 308.94 & 238 & 238.87 & 28410.5 & -5.1 & .00 \\
\hline Social environment & 317 & 265.62 & 236 & 292.28 & 33799.5 & -1.9 & .05 \\
\hline Advice of family or friends & 317 & 275.83 & 236 & 278.57 & 37036.0 & -.21 & .84 \\
\hline Interest in the subject & 319 & 289.61 & 235 & 261.06 & 33618.0 & -2.1 & .03 \\
\hline Individual talent & 318 & 270.35 & 236 & 287.14 & 35249.5 & -1.2 & .21 \\
\hline Acquiring knowledge & 319 & 271.83 & 236 & 286.34 & 35673.0 & -1.1 & .26 \\
\hline Life-realization & 318 & 273.68 & 237 & 283.80 & 36309.5 & -.74 & .45 \\
\hline Avoiding routine work & 316 & 276.64 & 237 & 277.48 & 37331.5 & -.06 & .95 \\
\hline broadening mental horizon & 320 & 270.61 & 237 & 290.32 & 35236.0 & -1.4 & .13 \\
\hline
\end{tabular}

Source: own elaboration based on data from 2016.

Since there are a correlations between motives for enrolling to university courses and the department affiliation of students further analyses are conducted. 
For further investigations with regard to the sample of students of the department of mechanical engineering, we used a multiple linear regression model. The aim was to explore which variables predict certain enrolling motives, starting with the item that students are motivated to attend higher education because they enjoy engaging with scientific issues. Therefore, the dependent variable examined was the preference of dealing with scientific issues. Table 3 shows that via multiple regression analysis we determined the following predictors for scientific aspiration: Students preferring to deal with scientific issues tend to perceive added value in research-driven teaching. They also have an aspiration to making a scientific career and prefer scientific working in general. The clear interest in their subject is also positively correlated with preferring to deal with scientific issues. The explained variance of this model is 58.9 percent.

Table 3. Results of multiple linear regression analysis of students of the department of mechanical engineering $(\mathrm{N}=306)$ at the KIT.

\begin{tabular}{lccccc}
\hline Variable & $\mathbf{B}$ & $\mathbf{S E}$ & $\boldsymbol{\beta}$ & $\mathbf{t}$ & $\mathbf{p}$ \\
\hline constant & 1.109 & .526 & - & 2.11 & .03 \\
$\begin{array}{l}\text { I perceive added value } \\
\text { in research-driven } \\
\text { teaching. }\end{array}$ & .125 & .039 & .136 & 3.32 & .00 \\
$\begin{array}{l}\text { Scientific working } \\
\begin{array}{l}\text { Aspiring a career in } \\
\text { science }\end{array}\end{array}$ & .501 & .046 & .536 & 11.0 & .00 \\
$\begin{array}{l}\text { Interest in the subject } \\
\text { Ine }\end{array}$ & .180 & .051 & .137 & 3.56 & .00 \\
\end{tabular}


Table 4. Results of multiple linear regression analysis of students of the department of economics and management $(\mathrm{N}=\mathbf{2 3 2})$ at the KIT.

\begin{tabular}{|c|c|c|c|c|c|}
\hline Variable & B & SE & $\boldsymbol{\beta}$ & $\mathbf{t}$ & $\mathbf{p}$ \\
\hline constant & 1.883 & .625 & - & 3.01 & .00 \\
\hline $\begin{array}{l}\text { I perceive added value } \\
\text { in research-driven } \\
\text { teaching. }\end{array}$ & .041 & .056 & .042 & .73 & .46 \\
\hline Scientific working & .466 & .060 & .521 & 7.75 & .00 \\
\hline $\begin{array}{l}\text { Aspiring a career in } \\
\text { science }\end{array}$ & .148 & .045 & .189 & 3.32 & .00 \\
\hline Interest in the subject & .178 & .065 & .135 & 2.75 & .00 \\
\hline
\end{tabular}

To compare the subsamples of students of both departments, we also conducted a multiple linear regression analysis of students of the department of economics and management with the same items (see table 4). The dependent variable of preference of engaging with scientific issues is positively correlated with an aspiration to making a career in science and a preference of scientific working in general. Via multiple regression analysis also a clear interest in their subject is salient. Up to this point, the predictors of the multiple regression analysis encompass no explicit distinction to their peers of the department of mechanical engineering. However, concerning the item "I perceive added value in research-driven teaching" a significant contrast to the sample of students affiliating to the department of mechanical engineering can be found. Preferring to deal with scientific issues is not correlated with perceiving an added value in research-driven teaching for students of the departments of economics and management. With an explained variance of 50.7 percent of this model, it fits to the half of the sample of students of the departments of of economics and management. As a preliminary conclusion, the outlined significant distinctions concerning their experiences with research and inquiry of students of the department of mechanical engineering and of the department of economics and management at the KIT, does not affect their subjective value of research-driven teaching.

\section{Conclusions}

Via chi-square-test, Mann-Whitney-U-Test and multiple regression analysis distinctions between students of the department of mechanical engineering and students of the department of economics and management concerning their experiences with various experiences of 
research and inquiry and also their motives of enrolling to university courses, specifying the the main results obtained.

This study suggests that universities should develop strategies for incorporating students' motives for enrolling to university courses and their experiences into strategies of assessing study programs. For answering the questions which directive strategies exist and if there is any imperative seen to review previous strategies at the department of mechanical engineering, interviews are planned. The interviews will address teachers affiliated to the the department of mechanical engineering to combine our research results with their valuable and relevant insights, such as course characteristics and cultural condition. Vice versa, with the current research results we are able to initiate a different perspective on decision-making patterns concerning the implementation and design of module handbooks in the selected departments.

\section{References}

Langemeyer, I., \& Schlindwein, N. (2021). Forschendes Lernen - ein Qualitätsmerkmal? Zur Schwierigkeit eines Nachweises über institutionelle Qualitätsverbesserungen durch forschungsorientierte Lehre. In T. Schmohl (Ed.), Hochschuldidaktische Begleitforschung. Theoretische, empirische und methodologische Perspektiven einer Hochschulbildungsforschung (in print). Bielefeld: transcript.

Tremp, P. (2018). Berufsbezug dank Forschendem Lernen? Zur Attraktivität einer hochschuldidaktischen Losung. In M. Fischer \& H.H. Kremer \& J. Gillen \& Langemeyer, I. (Eds.), Was berufliche und akademische Bildung trennt und verbindet. Entgrenzungen an der Schnittstelle von Berufsschule, Betrieb, Hochschule und Universität (pp. 1-14). Schwerpunktheft der der Zeitschrift bwp@34.

Trigwell, K., \& Prosser, M. (2004). Development and Use of the Approaches to Teaching Inventory. Educational Psychology Review, 16(4), 409-424. https://doi.org/10.1007/s10648-004-0007-9. 